\title{
PEMODELAN KAWASAN PASAR SOUVENIR DI DESA TOMOK (Objek Kasus : Desa Wisata Tomok, Kabupaten Samosir, Sumatera Utara)
}

\author{
Ida Nova Sitohang( ${ }^{(1)}$, Ir. Raimundus Pakpahan, MT $^{(2)}$, Shanty Silitonga ST,.MT ${ }^{(3)}$
}

(1) Mahasiswa, Prodi Arsitektur, Fakultas Teknik, Universitas Katolik Santo Thomas Sumatera Utara

(2) Staff pengajar, Prodi Arsitektur, Fakultas Teknik, Universitas Katolik Santo Thomas Sumatera Utara Email : pakpahanray@yahoo.co.id

(3) Staff pengajar, Prodi Arsitektur, Fakultas Teknik, Universitas Katolik Santo Tthomas Sumatera Utara Email : shanty.silitonga@gmail.com

\begin{abstract}
The tourist market or souvenir shop is a place of sale and purchase transactions in the tourist area that sells merchandise. The tourism market can be classified into traditional markets according to the physical, time, area of activities and goods traded. The tourism market can also be classified as a traditional market according to its function as culture, a market that has multi roles, not only acts as a meeting place between sellers and buyers but the market also has a function as a meeting place for each of those who use the market. Trading is one of the economic activities of the Tomok tourism village. The souvenir shop shows a lot of variants in terms of size / area, shape and ownership of the shop. It is importance to provide the right model in the souvenir market area in Tomok village. The research is using Modelling methodology. The benefit of this study is to find a model of the souvenir market area in Tomok tourism village that meets the souvenir market criteria.
\end{abstract}

Keywords: Tourism, Tomok, Souvenir Market, Model

\begin{abstract}
Abstrak
Pasar wisata atau souvenir shop merupakan sebuah tempat transaksi jual beli di daerah objek wisata yang menjual barang dagangan khas objek wisata tersebut. Pasar wisata dapat digolongkan pada pasar tradisional menurut fisik, waktu, luas kegiatan dan barang yang diperjual-belikan. Pasar wisata juga dapat digolongkan pasar tradisional menurut fungsinya sebagai budaya yaitu pasar yang memiliki multi peran, tidak hanya berperan sebagai tempat bertemunya antara penjual dan pembeli tetapi pasar juga memiliki fungsi sebagai tempat bertemunya budaya yang dibawa oleh setiap mereka yang memanfaatkan pasar. Berdagang merupakan salah satu kegiatan ekonomi masyarakat desa wisata tomok demi mencukupi kebutuhan masyarakat tersebut. Ditinjau berdasarkan keadaan bangunan toko souvenir menunjukkan banyak variasai dari segi ukuran/luas, bentuk serta kepemilikan toko. Salah satu jenis dagangannya yaitu souvenir khas desa tomok. Diperlukan sebuah model yang tepat pada kawasan pasar souvenir di desa tomok demi meningkatkan kunjungan wisatawan terhadap ojek wisata. Penelitian ini menggunakan metode pemodelan. Tujuan penelitian ini yaitu menemukan model kawasan pasar souvenir di desa wisata tomok yang memenuhi kriteri penataan pasar.
\end{abstract}

\section{Kata kunci: Wisata, Tomok, Pasar Souvenir, Model}

\section{Pendahuluan}

Dalam era globalisai saat ini, kegiatan wisata menjadi salah satu kebutuhan di dalam kehidupan manusia, pariwisata merupakan salah satu sektor yang diandalkan pemerintah untuk memperoleh devisa dari penghasilan non-migas. Salah satu tempat wisata budaya indonesia yang sudah dikenal sejak dulu adalah danau toba, kabupaten samosir tunjunk melalui UU no. 36/2003 ditempatkan sebagai salah satu pariwisata yang paling diandalkan. Salah satunya wisata budaya tomok yang terletak di kecamatan simanindo kabupaten samosir yang merupakan salah satu objek wisata budaya yang sering di kunjungi wisatawan lokal maupun mancanegara. 
Pada desa wista tomok terdapat beberapa fasilitas yang menunjang wisata seperti pedagang, rumah makan, restaurant, penginapan dan pusat informasi pada objek wisata tersebut. Salah satu bentuk pelayanan wisata yaitu dengan menyediakan fasilitas penunjang produk wisata yaitu usaha mendirikan toko souvenir yang memiliki jumlah sebanyak 260 toko souvenir (Dinas Pariwisata dan Seni Budaya Kabupaten Samosir, 2012). Di tinjau berdasarkan keadaan angunan toko souvenir menunjukan banyak variasi dari segi ukuran/luas, bentuk serta kepemilikan toko. Hal ini mempengaruhi nilai estetika atau cerminan yang ditunjukan oleh keberadaan toko souvenir sebagai salah satu sarana di kawasan objek wisata desa tomok.

Berdagang merupakan salah satu kegiatan ekonomi masyarakat desa wisata tomok demi mencukupi kebutuhan masyarakat tersebut. Salah satu jenis dagangannya yaitu souvenir, dimana souvenir merupakan hasil kerajinan masyarakat tersebut yang memiliki ciri khas batak toba. Pedagang souvenir sekitar desa tomok semakin bertambah sehingga memakan badan jalan utama menuju pelabuhan wisata tomok dab berakibat jalan menjadi macet. Tidak adanya perbedaan jalan terhadap pejalan kaki dan pengendara sehingga pada saat wisatawan ingin berbelanja pengendara roda 4 dan roda 2 terhambat sehingga menimbulkan kemacetan dan membuat wisatawan tidak nyaman dalam berjalan kaki. Berdasarkan permasalahan diatas peneliti tertarik melakukan penelitian pada kawasan pasar souvenir di desa wisata tomok untuk mendapatkan pemodelan terhadap pasar souvenir.

\section{Tinjauan pustaka}

Pasar Wisata atau Shouvenir shop adalah sebuah tempat bertemunya antara penjual dan pembeli yang didalamnya terjadi transaksi jual beli tapi letaknya ada di Daerah Tujuan Wisata (DTW), dan barangbarang yang dijualpun adalah barang-barang khas dari daerah tersebut sesuai dengan karakteristik dan kondisi daerah setempat. Dengan dibangunnya pasar wisata tersebut pemerintah daerah setempat memiliki tujuan agar dapat menarik wisatawan baik dari dalam maupun dari luar negeri, selain mendatangi obyek wisata yang ada.

Pasar wisata dapat digolongkan pada pasar tradisonal menurut fisik, waktu, luas kegiatan, dan barang yang diperjual-belikan. Pasar wisata juga dapat golongkan pasar tradisional menurut fungsinya sebagai budaya yaitu pasar yang memiliki multi peran, tidak hanya berperan sebagai tempat bertemunya antara penjual dan pembeli tetapi pasar juga memiliki fungsi sebagai tempat bertemunya budaya yang dibawa oleh setiap mereka yang memanfaatkan pasar. Menurut (Seymour M. Gold, 1980, pada Ade Cahya Tristyanthi, 2008), kriteria penilaian pasar sebagai berikut:

\begin{tabular}{|c|c|c|c|c|c|c|c|}
\hline \multirow[t]{2}{*}{ No. } & \multirow{2}{*}{ Sarana/prasarana } & \multicolumn{6}{|c|}{ Kriteria } \\
\hline & & Aksesbilitas & Keamanan & Keselamatan & Kenyamanan & Estetika & Kecukupan \\
\hline 1. & Kios Dagang & \begin{tabular}{|lr} 
- Setiap kios & dagang \\
dapat & mudah \\
diakses & oleh \\
pengguna & pasar. \\
(Ade & Cahya \\
Tristyanthi, 2008). & \\
- Kios-kios & yang \\
disediakan & harus \\
mempunyai tipe dan \\
dimensi yang sesuai \\
dengan & karakter \\
komoditas & jualan \\
(Agus & $\mathrm{S}$. \\
Ekomadyo) &
\end{tabular} & \begin{tabular}{|lr|}
\multicolumn{2}{|l|}{ Menggunakan } \\
bahan kontruksi \\
yang & tahan lama \\
(Ade r Cahya \\
Tristyanthi, 2008).
\end{tabular} & $\begin{array}{|lr|}\text { Kondisi } & \text { kios baik, } \\
\text { tidak } & \text { mudah } \\
\text { runtuh, } & \text { tidak } \\
\text { membahayakan } & \\
\text { keselamatan (Ade } \\
\text { Cahya } & \text { Tristyanthi, } \\
2008 \text { ) }\end{array}$ & $\begin{array}{l}\text { Kios dagang bersih } \\
\text { dan tidak } \\
\text { menghalangi } \\
\text { sirkulasi (Agus S. } \\
\text { Ekomadyo) }\end{array}$ & $\begin{array}{l}\text { - Kios dagang } \\
\text { menarik dan } \\
\text { menyenangkan } \\
\text { melalui indera } \\
\text { (Ade Cahya } \\
\text { Tristyanthi, } \\
\text { 2008) } \\
\text { - Perancangan } \\
\text { bangunan harus } \\
\text { menggunakan } \\
\text { elemenelemen } \\
\text { arsitektur lokal } \\
\text { (Agus } \mathrm{S} . \\
\text { Ekomadyo) }\end{array}$ & $\begin{array}{l}\text { - Ukuran kios } \\
\text { mencukupi } \\
\text { kebutuhan } \\
\text { perdagang dan } \\
\text { pembeli untuk } \\
\text { beraktivitas. (Ade } \\
\text { Cahya Tristyanthi, } \\
\text { 2008) } \\
\text { - Kios dengan ukuran } \\
4 \mathrm{~m}^{2}, 8 \mathrm{~m}^{2}, 12 \mathrm{~m}^{2}, 16 \\
\mathrm{~m}^{2}, \text { dan } 24 \mathrm{~m}^{2} \text {. (UU } \\
\text { No. } 9 \text { Tahun 2014) }\end{array}$ \\
\hline 2. & Gang Antar Kios & $\begin{array}{l}\text { Gang tertata dengan } \\
\text { baik sehingga dapat } \\
\text { memudahkan }\end{array}$ & $\begin{array}{l}\text { - Gang tidak } \\
\text { terlalu sempit dan } \\
\text { berdesakan. }\end{array}$ & $\begin{array}{l}\text { Gang bersih dari } \\
\text { rintangan yang } \\
\text { menghalangi } \\
\text { sirkulasi jalan. }\end{array}$ & $\begin{array}{ccc}\text { - Gang } & \text { dapat } \\
\text { dilalui } 2 & \text { orang } \\
\text { dan tidak } & \text { saling } \\
\text { berdesakan. (Ade }\end{array}$ & $\begin{array}{l}\text { Gang bersih, } \\
\text { menarik dan mudah } \\
\text { maintenancenya }\end{array}$ & $\begin{array}{l}\text { - Lebar gang tidak } \\
\text { terlalu sempit untuk } \\
\text { dilalui minimal } 2 \\
\text { orang. (Ade Cahya }\end{array}$ \\
\hline
\end{tabular}


Jurnal Arsitektur ALUR - Vol.2 No.1 April 2019

\begin{tabular}{|c|c|c|c|c|c|c|c|}
\hline & & $\begin{array}{l}\text { sirkulasi. (Ade Cahya } \\
\text { Tristyanthi, 2008) }\end{array}$ & 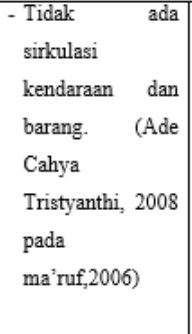 & $\begin{array}{l}\text { (Ade Cahya } \\
\text { Tristyanthi, 2008) }\end{array}$ & \begin{tabular}{|l|} 
Cahya \\
Tristyanthi, 2008) \\
- Area publik dan \\
sirkulasi harus \\
dirancang dengan \\
memaksimalkan \\
sirkulasi udara \\
silang. (Agus S. \\
Ekomadyo)
\end{tabular} & \begin{tabular}{|l|} 
(Ade Cahya \\
Tristyanthi, 2008)
\end{tabular} & $\begin{array}{l}\text { Tristyanthi, } 2008 \\
\text { pada ma'ruf,2006) } \\
\text { - Sirkulasi harus } \\
\text { dirancang dengan } \\
\text { memaksimalkan } \\
\text { sirkulasi udara } \\
\text { silang (Agus S. } \\
\text { Ekomadyo) }\end{array}$ \\
\hline 3. & Jalan Utama & $\begin{array}{l}\text { Jalan utama mudah } \\
\text { ditemukan dan } \\
\text { dicapai (Ade Cahya } \\
\text { Tristyanthi, 2008) }\end{array}$ & $\begin{array}{l}\text { Jalan tidak licin, } \\
\text { dan penggunaan } \\
\text { material yang tidak } \\
\text { mengganggu } \\
\text { pejalan kaki. (Ade } \\
\text { Cahya Tristyanthi, } \\
2008 \text { ) }\end{array}$ & 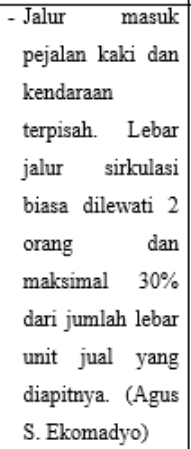 & 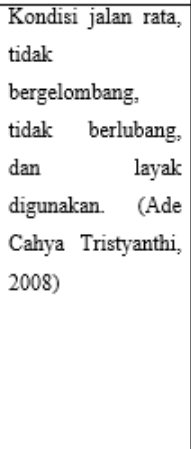 & & $\begin{array}{l}\text { - Jalan masuk cukup } \\
\text { lebar untuk } 2 \text { orang } \\
\text { jalan beriringan., } \\
\text { dan dapat dilalui } \\
\text { kendaraan darurat } \\
\text { seperti ambulans } \\
\text { dan pemadam } \\
\text { kebakaran. (Ma'ruf, } \\
2006 \text { pada Ade } \\
\text { Cahya Tristyanthi, } \\
\text { 2008). }\end{array}$ \\
\hline
\end{tabular}

\begin{tabular}{|c|c|c|c|c|c|c|c|}
\hline & & & & \begin{tabular}{|l} 
- Tidak adanya \\
jalur sirkulasi \\
kendaraan. (Ade \\
Cahya \\
Tristyanthi, \\
2008)
\end{tabular} & & & $\begin{array}{l}\text { - Pintu masuk dan } \\
\text { hierarki sirkulasi } \\
\text { harus dirancang agar } \\
\text { semua area pasar } \\
\text { mudah dijangkau } \\
\text { (Agus } \\
\text { Ekomadyo) } \\
\text { - Unit-unit jual harus } \\
\text { mendapatkan } \\
\text { aksesibilitas visual } \\
\text { yang memadai dari } \\
\text { pengunjung (Agus } \\
\text { S. Ekomadyo) }\end{array}$ \\
\hline 4. & Identitas & $\begin{array}{l}\text { Papan informasi } \\
\text { letaknya meraik untuk } \\
\text { dilihat (Ade Cahya } \\
\text { Tristyanthi, 2008) }\end{array}$ & $\begin{array}{l}\text { Papan informasi } \\
\text { tidak mengganggu } \\
\text { pemandangan } \\
\text { pejalan kaki, dan } \\
\text { tidak mengganggu } \\
\text { pejalan kaki saat } \\
\text { berjalan kaki. (Ade }\end{array}$ & $\begin{array}{lr}\text { Papan informasi } \\
\text { mudah dijangkau } \\
\text { penglihatan pejalan } \\
\text { kaki, dan } & \text { tidak } \\
\text { terkena } & \text { fisik } \\
\text { pejalan } & \text { kaki. (Ade } \\
\text { Cahya } & \text { Tristyanthi, } \\
2008) & \end{array}$ & $\begin{array}{l}\text { Papan informasi } \\
\text { mudah dimengerti } \\
\text { dan dapat dibaca } \\
\text { dengan jelas. (Ade } \\
\text { Cahya Tristyanthi, } \\
2008 \text { ) }\end{array}$ & $\begin{array}{l}\text { Menarik perhatian } \\
\text { pengunjung (Ade } \\
\text { Cahya Tristyanthi, } \\
\text { 2008) }\end{array}$ & $\begin{array}{l}\text { Tersedia beberapa } \\
\text { papan informasi yang } \\
\text { menunjukkan arah ke } \\
\text { bagian pasar yang } \\
\text { sulit ditemukan. (Ade } \\
\text { Cahya Tristyanthi, } \\
2008)\end{array}$ \\
\hline
\end{tabular}

\begin{tabular}{|c|c|c|c|c|c|c|c|}
\hline & & & $\begin{array}{l}\text { Cahya Tristyanthi, } \\
\text { 2008) }\end{array}$ & & & & \\
\hline 5. & Toilet & $\begin{array}{l}\text { Toilet umum mudah } \\
\text { ditemukan (Ade } \\
\text { Cahya Tristyanthi, } \\
\text { 2008) }\end{array}$ & $\begin{array}{l}\text { Mudah dijangkau, } \\
\text { penggunaan } \\
\text { material yang tidak } \\
\text { licin. (Ade Cahya } \\
\text { Tristyanthi, 2008) }\end{array}$ & $\begin{array}{l}\text { Kondisi toilet baik } \\
\text { dan tidak } \\
\text { membahayakan } \\
\text { keselamatan. (Ade } \\
\text { Cahya Tristyanthi, } \\
2008)\end{array}$ & $\begin{array}{l}\text { Penggunaan } \\
\text { material yang tidak } \\
\text { membahayakan. } \\
\text { (Ade Cahya } \\
\text { Tristyanthi, 2008) }\end{array}$ & $\begin{array}{lr}\text { Toilet } & \text { menarik } \\
\text { sehingga } & \text { dapat } \\
\text { dengan } & \text { mudah } \\
\text { dikenali } & \text { oleh } \\
\text { pengunjung. (Ade } & \\
\text { Cahya } & \text { Tristyanthi, } \\
2008) & \end{array}$ & $\begin{array}{l}\text { - Toilet tersedia } \\
\text { mencukupi } \\
\text { kebutuhan. (Ade } \\
\text { Cahya Tristyanthi, } \\
\text { 2008) }\end{array}$ \\
\hline 6. & Drainase & $\begin{array}{lr}\text { Drainase } & \text { mudah } \\
\text { untuk di } & \text { bersihkan } \\
\text { (Ade } & \text { Cahya } \\
\text { Tristyanthi, 2008) }\end{array}$ & $\begin{array}{l}\text { Drainase } \\
\text { menggunakan } \\
\text { material buis beton } \\
\text { dan menggunakan } \\
\text { penutup drainase. } \\
\text { (Ade Cahya } \\
\text { Tristyanthi, 2008) }\end{array}$ & $\begin{array}{l}\text { Drainase tidak } \\
\text { membahayakan } \\
\text { keselamatan } \\
\text { pejalan kaki (Ade } \\
\text { Cahya Tristyanthi, } \\
2008 \text { ) }\end{array}$ & $\begin{array}{l}\text { Penggunaan } \\
\text { material yang tidak } \\
\text { membahayakan. } \\
\text { (Ade Cahya } \\
\text { Tristyanthi, 2008) }\end{array}$ & $\begin{array}{lr}\text { Toilet } & \text { menarik } \\
\text { sehingga } & \text { dapat } \\
\text { dengan } & \text { mudah } \\
\text { dikenali } & \text { oleh } \\
\text { pengunjung. (Ade } \\
\text { Cahya Tristyanthi, } \\
2008 \text { ) }\end{array}$ & $\begin{array}{l}\text { - Toilet tersedia } \\
\text { mencukupi } \\
\text { kebutuhan. (Ade } \\
\text { Cahya Tristyanthi, } \\
\text { 2008) }\end{array}$ \\
\hline 7. & Parkir & $\begin{array}{l}\text { Tempat parkir mudah } \\
\text { diakse pintu keluar } \\
\text { dan masuk dengan } \\
\text { mudah. (Ade Cahya } \\
\text { Tristyanthi, 2008) }\end{array}$ & $\begin{array}{l}\text { Pintu masuk dan } \\
\text { keluar parkir tidak } \\
\text { membingung } \\
\text { pengunjung. (Ade }\end{array}$ & $\begin{array}{lr}\text { Tersedia } & \text { petugas } \\
\text { pengatur parkir. } \\
\text { (Ade } \quad \text { Cahya } \\
\text { Tristyanthi, 2008) }\end{array}$ & $\begin{array}{l}\text { - Tempat parkir } \\
\text { culup } \\
\text { mendapatkan } \\
\text { cahaya. (Ma'ruf, } \\
2006 \text { pada Ade }\end{array}$ & & $\begin{array}{l}\text { - Luas area parkir } \\
\text { harus mampu } \\
\text { menampung } \\
\text { kendaraan } \\
\text { pengunjung sesuai }\end{array}$ \\
\hline
\end{tabular}




\begin{tabular}{|c|c|c|c|c|c|}
\hline & & & $\begin{array}{l}\text { Cahya Tristyanthi, } \\
\text { 2008) }\end{array}$ & \begin{tabular}{|lr|}
\multicolumn{2}{|l|}{ Cahya } \\
Tristyanthi, 2008) \\
- Terdapat garis- \\
garis pembatas \\
parkir yang sesuai \\
dengan & ukuran \\
mobil r motor. & \\
(Triyono, 2006 \\
pada Ade & Cahya \\
Tristyanthi, 2008)
\end{tabular} & \begin{tabular}{|lr}
\multicolumn{1}{|l|}{ dengan karakter } \\
pengunjung pasar \\
(Agus $\mathrm{S}$. \\
Ekomadyo) \\
- Area parkir harus \\
diletakkan berkaitan \\
dengan pintu masuk \\
bangunan pasar dan \\
mendorong \\
pengunjung untuk \\
melewati area \\
tertentu didalam \\
pasar (Agus $\mathrm{S}$. \\
Ekomadyo)
\end{tabular} \\
\hline 8. & $\begin{array}{l}\text { Tempat } \\
\text { Pembuangan } \\
\text { Sampah }\end{array}$ & 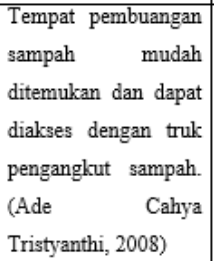 & & \begin{tabular}{|lr|}
\multicolumn{2}{|l|}{ - -empat } \\
pembuangan \\
$\begin{array}{lr}\text { sampah } & \text { tidak } \\
\text { menyatu } & \text { dengan } \\
\text { kios-kios } & \text { pasar. } \\
\text { (Ade } & \text { Cahya } \\
\text { Tristyanthi, 2008) }\end{array}$
\end{tabular} & $\begin{array}{l}\text { - Besarnya tempat } \\
\text { pembungan sampah } \\
\text { mencukupi } \\
\text { kebutuhan (Ade } \\
\text { Cahya Tristyanthi, } \\
\text { 2008). }\end{array}$ \\
\hline
\end{tabular}

Berdasarkan tinjauan teori diatas terdapat beberapa sarana dan prasarana yang berperan dalam penataan pasar yang menunjang keberadaan penilaian pasar sebagai ruang publik.

\section{Metodologi penelitian}

Penelitian ini digolongkan dalam penelitian yng menggunakan startegi penelitian simulasi dan pemodelan yang kemudian di kombinasikan dengan metode kualitatif. Dengan mengumpulkan data secara primer dan sekunder yang mengenai fenomena yang terjadi dilapangan . setelah mengkaji hasil pengamatan di lapangan kemudian mengkaji teori mengenai kriteria pasar souvenir (pasar wisata) yang akan digunakan untuk mengetahui kriteria dasar pasar wisata secara umum.

\section{Deskripsi objek penelitian}

Lokasi objek studi yang diambil pada pemodelan kawasan pasar souvenir adalah sepanjang jalan mulai dari pelabuhan kapal wisata tomok sampai pada pintu masuk menuju wisata sigale-gale, desa wisata tomok yang merupakan para pedagang souvenir yang menggunakan kios sebagai tempat berjualan sepanjang jalan menuju pintu masuk wisata sigale-gale. Pada kawasan pasar souvenir ini berjumlah 305 kios dan memiliki ukuran yang tidak terlalu besar. Kondisi pada kawasan pasar souvenir saat ini terlihat rapi, kios yang sudah tertata oleh pelindo hanya saja pada saat berjalan menuju pintu masuk wisata sigale-gale, terlihat sempit dan gelap, dikarenakan begitu banyak pengunjung yang hendak membeli souvenir di lokasi ini. Para pedagang yang masih memakan badan jalan sehingga akses berjalan kaki untuk pengunjung berkurang, sehingga kurangnya kenyamanan pengunjung pada saat berbelanja.

\section{Analisa}

Pada kasus 1 (kios dagang), kios dagang terlihat biasa saja tidak menarik, pada kios dagang menggunakan material atap seng, dan dinding papan.

Usulan : berdasarkan fenomena dilapangan pada kios dagang akan lebih dimodelkan pada estetika kios dagang. Pemodelan kios dagang akan lebih kontekstual pada arsitektur lokal yaitu arstektur batak toba yang nantinya lebih ke fasad kios dagang dengan menggunkan material yang kokoh. 


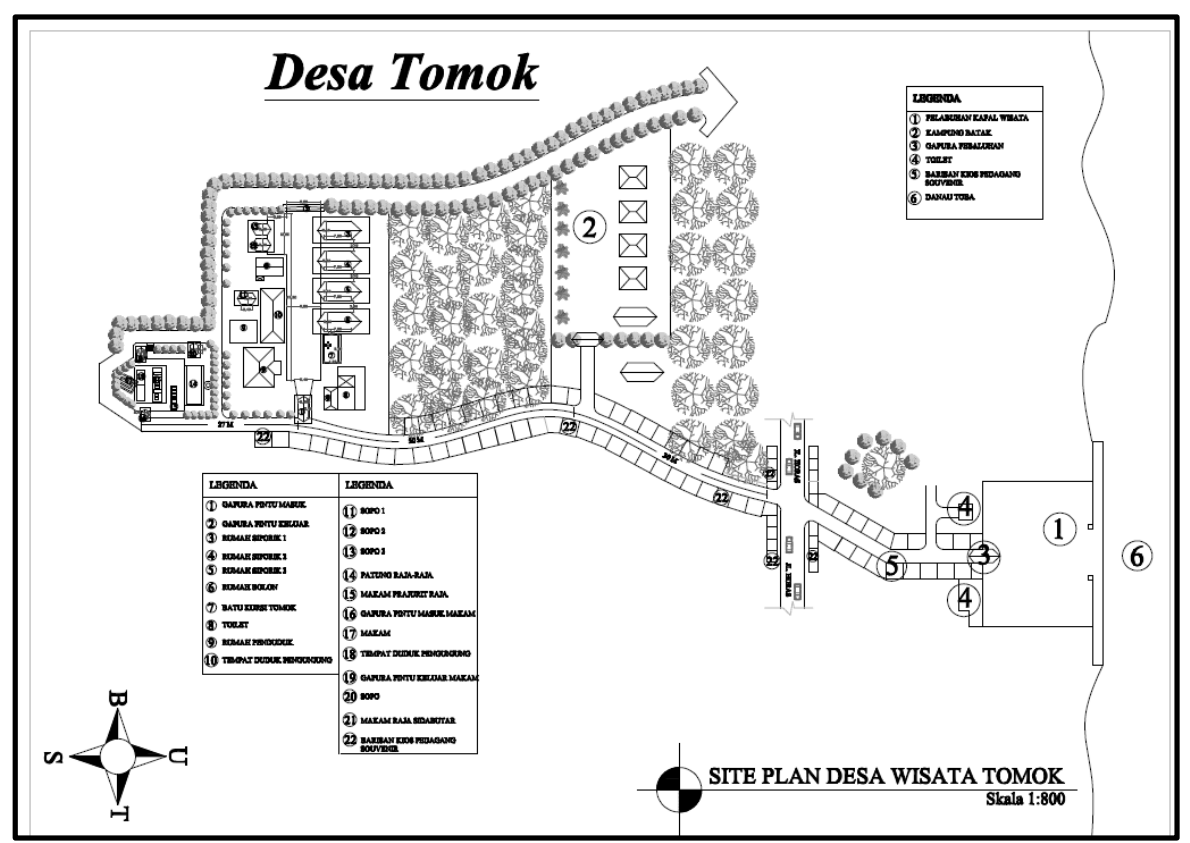

Gbr 1. Site Plan Kawasan Pasar

\section{Konsep :}
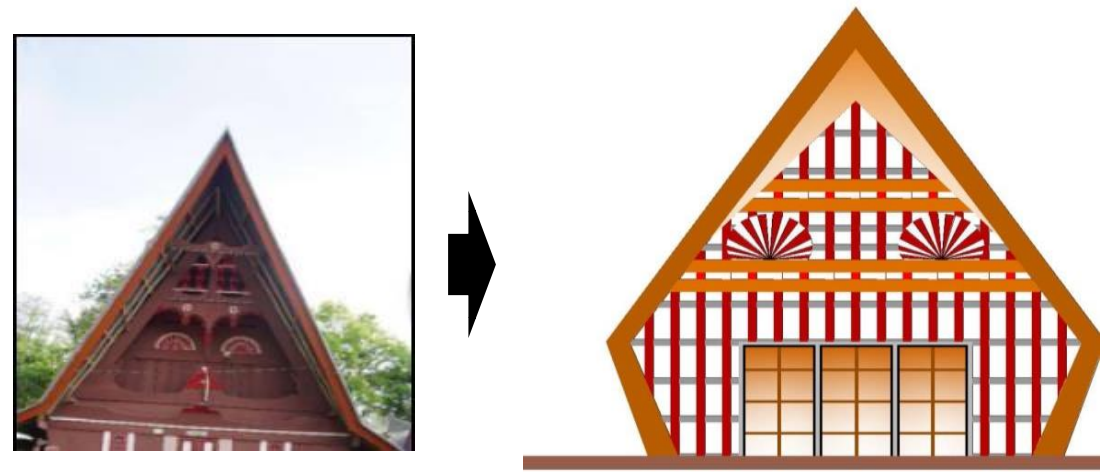

Pada kasus 2 (gang antar kios), gang antar kios terlihat biasa saja tidak menarik, tidak adanya penunjuk pada gang antar kios sehingga membingungkan pengunjung.

Usulan : berdasarkan fenomena dilapangan pada gang antar kios dakan lebih di modelkan pada estetika gang antar kios. Pemodelan gang antar kios akan lebih kontekstual pada arsitektur lokal yaitu arsitektur batak toba yang nantinya lebih ke fasad gang antar kios dengan menggunakan material yang kokoh.

Konsep : Pada atap gapura konteks pada atap rumah batak, dan pada tiang menggunakan patung raja dompak 


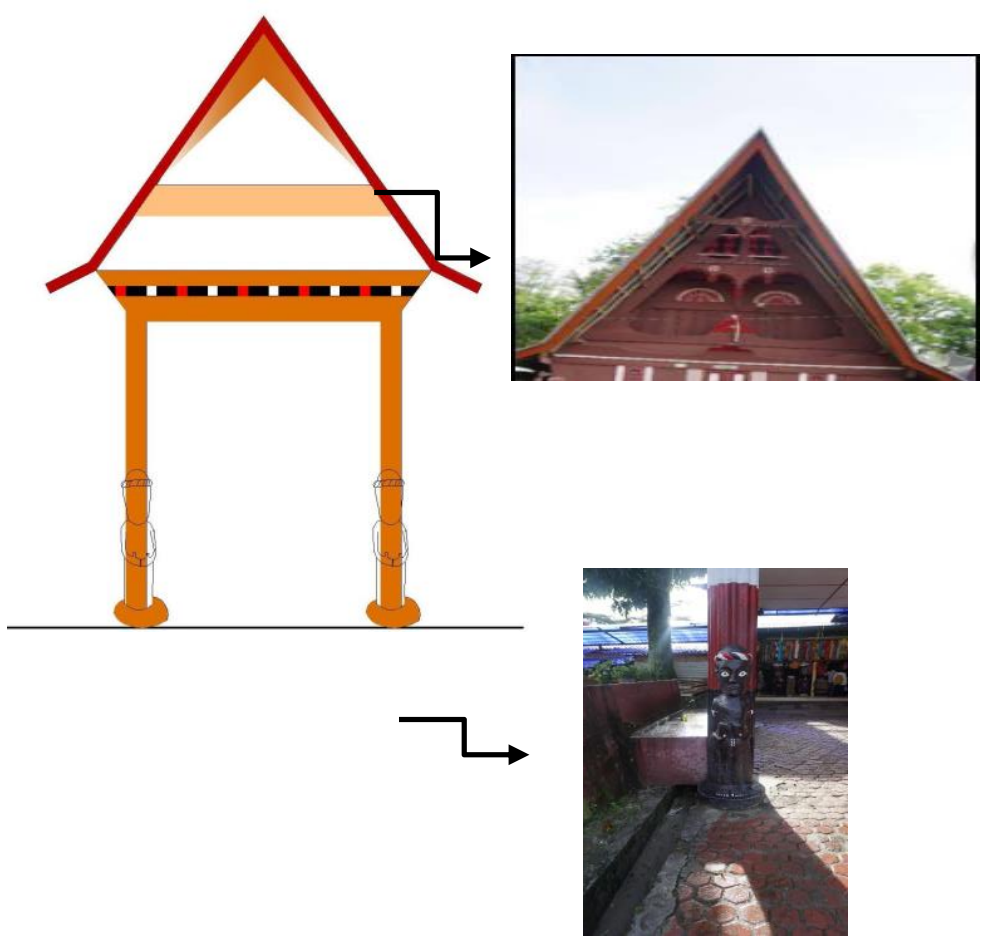

Pada kasus 3 (identitas atau papan informasi), tidak terdapat papan informasi pada sepanjang kawasan pasar souvenir, sehingga membingungkan para pengunjung yang ingin berbelanja pada pasar souvenir.

Usulan : Menggunakan papan informasi seperti banner yang akan diletakkan sepanjang jalan kawasan pasar souvenir tersebut.
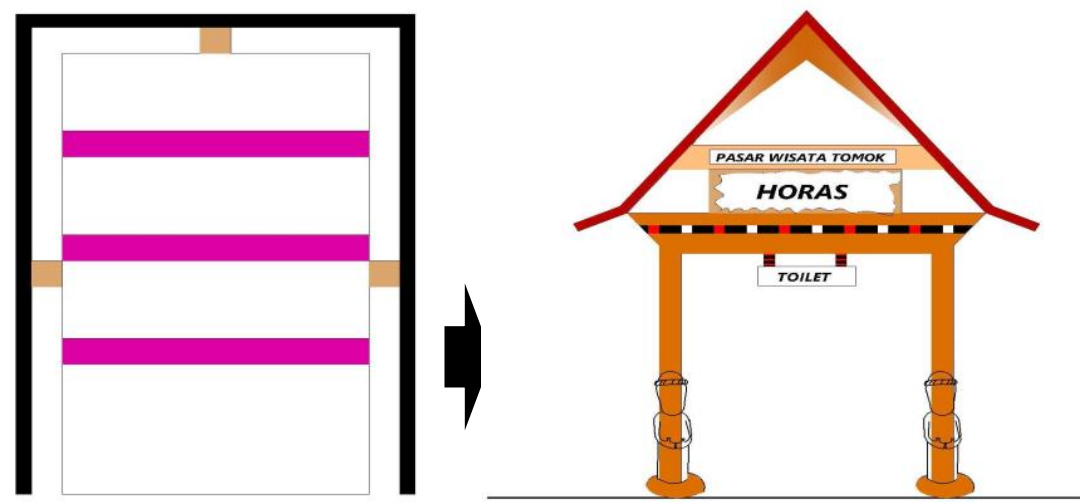

Pada kasus 4 (toilet), terdapat toilet pada setiap gang, namun toilet terlihat tidak menarik dan biasa saja. Pada toilet menggunakan tidak licin dan pada pintu masuk menggunakan paving block agar tidak licin pada saat turunn hujan.

Usulan : toilet akan lebih pada estetika agar lebih menarik perhatian pengunjung yang hendak ke toilet. Menggunakan tiang sebagai papan informasi pada toilet. Pada atap toilet konteks dengan atap rumah adat batak toba. 


\section{Konsep :}
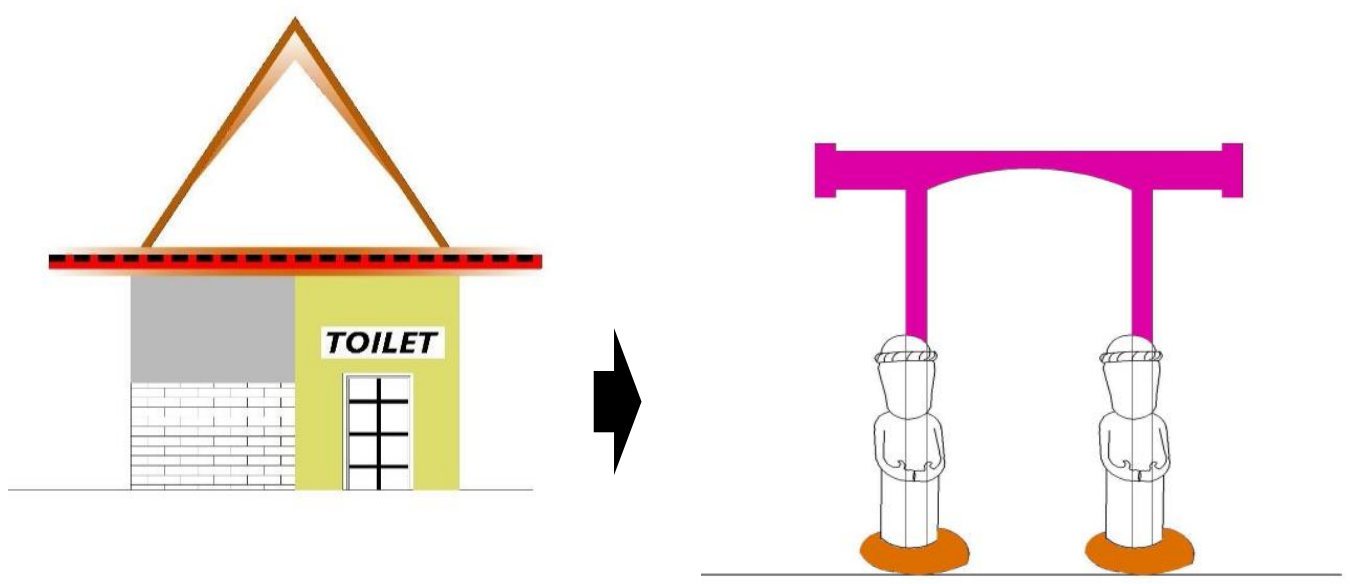

Pada kasus 5 (tempat pembuangan sampah), tidak terdapat tempat pembuangan sampah pada sekitaran kawasan pasar souvenir, para pedagang souvenir memungut sampah masing-masing dan menggunakan tempat sampah sendiri.

Usulan : Akan dibedakan tempat sampah antara sampah organik dan sampah non-organik, yang akan diletakkan disamping kios dagang agar tidak menghalangi sirkulasi pejalan kaki pada saat berbelanja dan hendak ingin ke desa wisata tomok.

\section{Konsep :}

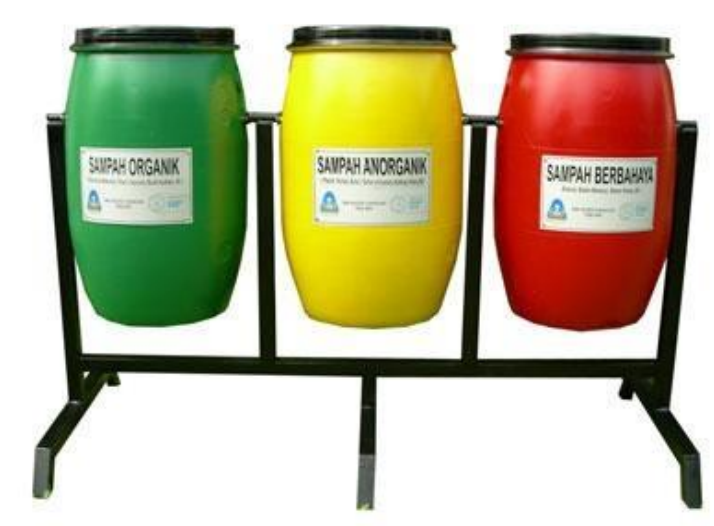

Berdasarkan tinjauan pustaka yang telah dikumpulkan dan dirangkum kemudian dianalisa yang disesuaikan dengan pengamatan pada kawasan pasar souvenir. Dalam analisa kualitatif terdapat beberapa komponen pasar yang tidak memenuhi kenyamanan yang disesuaikan dengan standar dan kriteria yang ada yaitu :

1. Kios dagang dalam estetika tidak "memenuhi" oleh karena itu mendesain kios dagang agar lebih menarik perhatian pengunjung dengan menerapkan konsep arsitektur lokal rumah adat batak toba yang dimana kios dagang menggunakan atap seperti rumah batak toba dan menggunakan ornamen batak toba pada bagian fasad kios dagang.

2. Gang antar kios dalam "keselamatan dan estetika" tidak memenuhi oleh karena itu perlunya pembatas antara barang dagangan pedagang agar tidak memakan badan jalan yang menghalangi 
sirkulasi pejalan kaki. Dan perlunya mendesain penanda gang antar kios agar menambah estetika tersendiri pada kawasan souvenir. Dengan menggunakan konsep arsitektur lokal rumah adat batak toba yang dimana gang antar kios menggunakan atap arsitektur lokal rumah adat batak toba yang dimana gang antar kios menggunakan atap seperti rumah batak toba dan menggunakan ornamen ipon-ipon dan patung gajah dompak pada bagian fasad dan tiang gapura gang antar kios.

3. Identitas pada beberapa kawasan pasar souvenir dalam "estetika dan kecukupan" tidak memenuhi, oleh karena itu mendesain ulang papan informasi agar lebih menarik perhatian wisatawan dan menambah fasilitas papan informasi sehingga pengunjung tidak sulit dalam mengakses area yang tidak kelihatan dengan konsep seperti banner yang berisikan rute-rute area pasar souvenir.

4. Toilet pada beberapa kawasan pasar souvenir dalam estetika tidak memenuhi oleh karena itu perlu mendesain toilet agar lebih menarik perhatian dengan menerapkan konsep arsitektur lokal rumah adat batak toba yang dimana toilet menggunakan atap rumah batak toba dan menggunakan ornamen ipon-ipon, menggunakan motif bata, serta menggunakan motif anyaman tikar pada bagian fasad.

5. Drainase pada beberapa kawasan dalam keselamatan tidak memenuhi, oleh karena itu menggunakan penutup drainase dari bahan besi agar tidak cepat rusak dan tidak menghalangi sirkulasi pejalan kaki.

6. Tempat pembuangan sampah tidak memenuhi dikarenakan tidak adanya tempat sampah, oleh karena itu perlunya adaa tempat sampah agar kawasan kios tetap bersih dan nyaman.

Dari hasil analisa tersebut kemudian akan di modelkan dalam bentuk 3D (tiga dimensi) sebagai memperjelas keadaan kawasan pasar souvenir.

\section{Pemodelan}

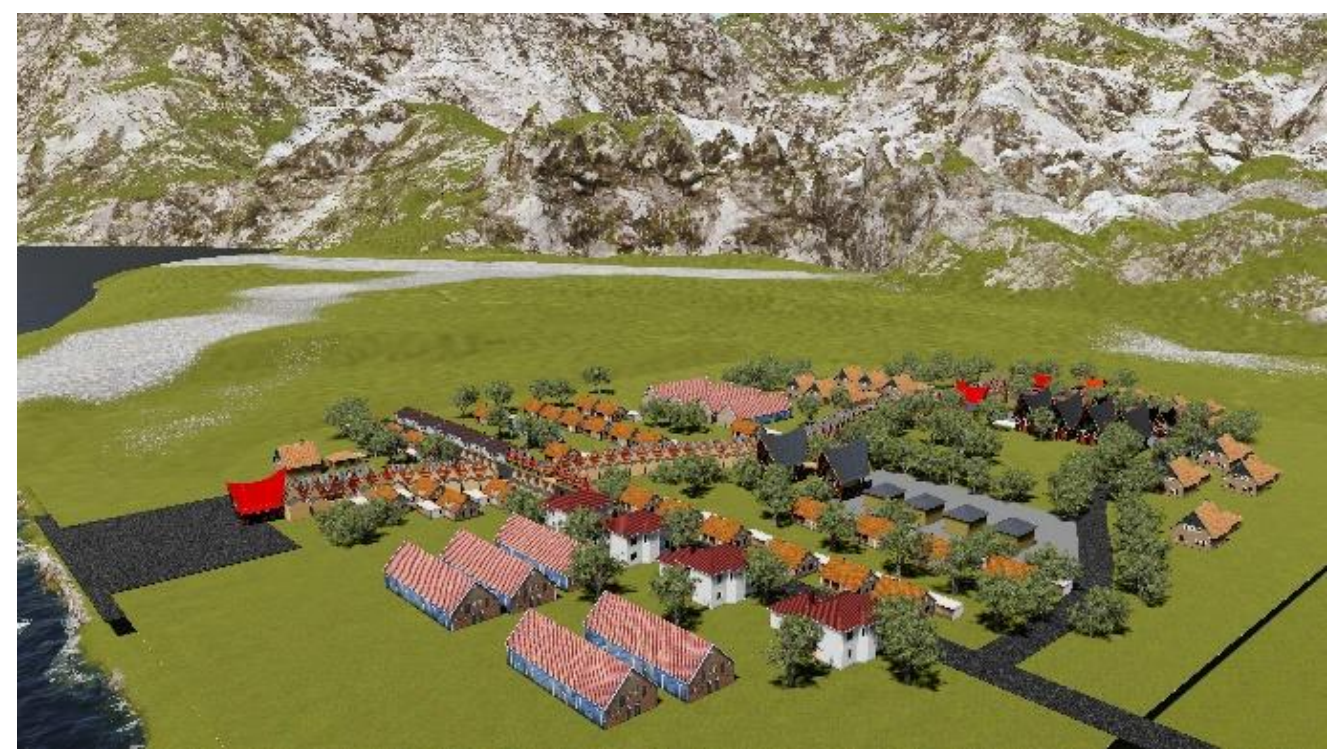

Gbr 2. Model site plan kawasan pasar souvenir 

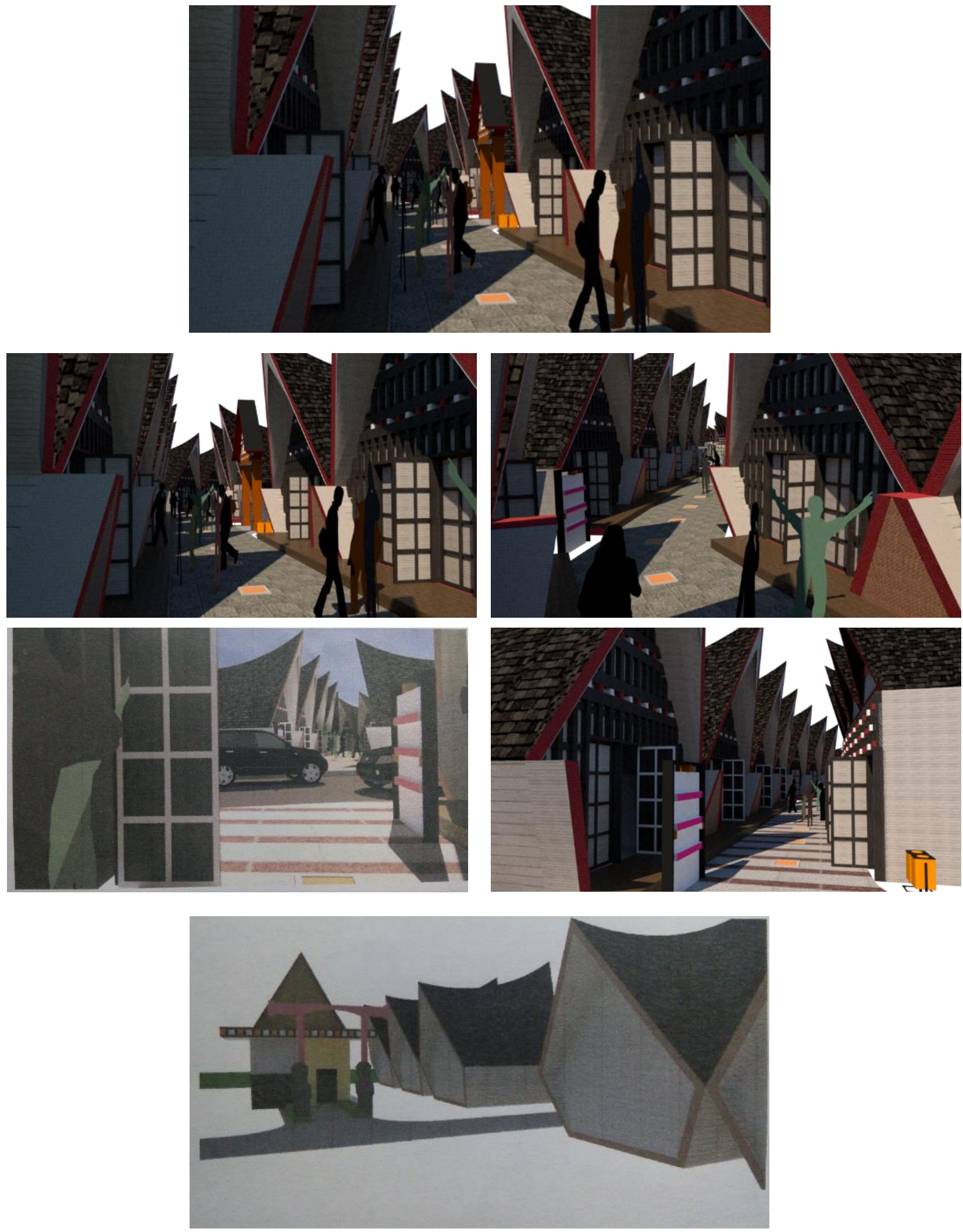

Gbr 3. Pemodelan kios dagang 


\section{Kesimpulan}

Pasar wisata atau souvenir adalah sebuah tempat bertemunya antara penjual dan pembeli yang didalamnya terjadi transaksi jual beli tapi letaknya berada didaerah tujuan wisata, dan barang yang di jual pun adalah barang-barang khas dari daerah tersebut sesuai dengan karakteristik dan kondisi daerah setempat. Pasar souvenir merupakan bagian dari sebuah tempat wisata yang sering dikunjungi oleh wisatawan lokal maupun wisatawan mancanegara untuk itu perlunya sebuah perencanaan dalam menata pasar souvenir yang sesuai dengan standar dan kriteria pasar yang dapat memenuhi kenyamanan bagi pengunjung dalam berbelanja di pasar souvenir tersebut. Dalam perencanaa menata pasar souvenir perlu memperhatikan aksesbilitas, keamanan, keselamatan, estetika dan kecukupan pasar souvenir dan tidak meninggalkan keaslian arsitektur lokal sekitar kawasan pasar souvenir.

Adapun saran yang disampaikan antara lain sebagai berikut :

1. Setiap kawasan memiliki kriteria penilaian yang memenuhi kenyamanan yang berbeda-beda dan tidak sama dengan kawasan lainnya. Seperti kios dagang untuk itu perlu adanya menata ulang kios dagang agar lebih menarik perhatian pengunjung.

2. Setiap kawasan pasar wisata (souvenir) perlu adanya fasilitas yang dapat menunjang keberhasilan sebuah pasar wisata (souvenir) desa wisata tomok parsaoran agar lebih menambah sarana/prasarana yang menunjang kegiatan pasar souvenir tersebut seperti toilet, identitas (papan informasi) agar wisatawan tidak kebingungan dalam memasuki rute pasar souvenir, tempat sampah agar lingkungan pasar souvenir tetap bersih dan nyaman, serta parkir agar tidak sering terjadinya macet pada jalan horas sehingga tidak mengganggu pengunjung saat berjalan kaki.

\section{Daftar Pustaka}

Seymour M. Gold, 1980, Kriteria Penilaian Pasar, Laporan Tugas Akhir, Institut Teknologi Bandung 2008.

Dinas Pariwisata dan Seni Budaya Kabupaten Samosir, 2012. Fasilitas Penunjang Wisata.

Agus S. Ekomadyo,2012, Isu, Tujuan Dan Kriteria Perancangan Pasar Tradisional. Temu Ilmiah IPLBI 2012.

PERATURAN MENTERI PERDAGANGAN REPUBLIK INDONESIA Nomor : 53/M-DAG/12/2008. Pada Bab 1 Menteri Perdagangan Tentang Pedoman Penataan Dan Pembinaan Pasar Tradisional, Pusat Perbelanjaan Dan Toko Modern. 